American Journal of Economics and Business Administration 2 (4): 341-349, 2010

ISSN 1945-5488

(C) 2010 Science Publications

\title{
Disclosure Factors of Executive Managers Remuneration: A Probit Model
}

\author{
${ }^{1}$ Themistokles Lazarides and ${ }^{2}$ Elektra Pitoska \\ ${ }^{1}$ Department of Applied Informatics in Business and Economy, \\ TEI of West Macedonia, Greece, 51100, Grevena, Greece \\ ${ }^{2}$ Department of Financial Applications, TEI of West Macedonia, \\ Greece, 50100, Kozani, Greece
}

\begin{abstract}
Problem statement: The study contributes to the literature that argues that the convergence trend of corporate governance systems is either nominal or hasn't the impact that the advocates of this theory hypothesize. Approach: The objective of the study was to test this hypothesis the key issue of remuneration had been chosen to illustrate that the differences of corporate governance systems still exist and they have a substantial impact on business environment. Disclosure or not of information regarding these issues preoccupies regulating, legislative authorities as well as capital market participants. The study, using a probit regression analysis, examined whether these differences are observable in Greece. Greece is a country with the typical characteristics of a Continental Europe corporate governance system. The results were compared with the reported characteristics of AngloSaxon countries. The study analyzed data over a period of 6 years (2001-2006). The 60 firms largest, in terms of capitalization and free float, were used. Results: The major factors that affect the remuneration disclosure were the adoption of mergers and acquisitions as the method to expand firm's size, the investments risks that the firm is willing to take, stock market capitalization, board of directors size, capital to sales ratio, number of independent board of directors member dismissals and the quality of corporate governance. These differences were significantly different than the ones reported for Anglo-Saxon countries. Conclusion: The study had proven that remuneration disclosure levels in Greece are defined by a different set of factors than the ones in a typical Anglo-Saxon country. Policy and regulation makers should take into account these differences and not adopt isomorphic approaches to different problems and situations.
\end{abstract}

Key words: Probit model, Compensation, board of directors, corporate governance

\section{INTRODUCTION}

The study focuses on the decision to disclose information regarding executive remuneration levels. Its main research question is that the factors that influence this decision are different than the ones in the Anglo-Saxon countries. The study contributes to the literature that argues that the convergence trend (Van den Berghe, 2002) of corporate governance systems is either nominal or hasn't the impact that the advocates of this theory hypothesize.

Executive-shareholder interest alignment is the focal point of agency theory. The basic mechanism proposed to solve the issue is remuneration (Grossman and Hart, 1983; Jensen et al., 2004). In order to establish a rationality in formulating remuneration policies the firm has to establish a method to verify the value of managers (Petra, 2005), managers' and directors' contribution to financial performance (Letza et al., 2008; Conyon et al., 1995; Gregg et al., 1993; Hassan et al., 2003) and the overall value of the firm (Habib and Ljungqvist, 2005; Stulz, 1990). From the perspective of stewardship theory (Donaldson, 1990; 1991; Barney and Hesterly, 2007) managers are not motivated only or mainly through remuneration. Other researchers (Petra, 2005) argue that it is necessary to enforce managers in order to enforce productivity. Remuneration control is exerted by the General Shareholders Meeting, the Board of Directors $(\mathrm{BoD})$ or by any committee that has been introduced to control and evaluate executive managers and their performance. The efficiency of these mechanisms has been the focal point of many studies (Petra, 2005; Conyon and Peck, 1998).

Some research findings (Bebchuk and Fried, 2004) showed that managerial power has dominated the process of negotiation for remuneration levels. $\mathrm{BoD}$ is

Corresponding Author: Themistokles Lazarides, Department of Applied Informatics in Business and Economy, TEI of West Macedonia, Greece, 51100, Grevena, Greece 
responsible for determining these levels and the schemes of remuneration. "In light of the historically weak link between non-equity compensation and managerial performance, shareholders and regulators wishing to make pay more sensitive to performance have increasingly looked to and encouraged, equitybased compensation-that is, compensation based on the value of the company's stock" (Bebchuk and Fried, 2004). During the last two-three years a debate (i.e., Pittsburgh and London summits of G-20) has been initiated in order to determine the optimal mix of equity and non equity remuneration as well as the optimal level of remuneration.

The theory that executives and directors should be motivated to align their interests with the shareholders' interests, has led to multiply by 5 (Samimi et al., 2009; Cassidy, 2002) the executives remunerations in a decade (1991-2001) and the disclosure of frauds. Furthermore executives are willing to invest free cash flows ineffectively, to retain the capital assets within the firm, rather than to distribute them to shareholders (Nguyen, 2005; Hellwig, 1998). The basic motive for the executives is the dominance in corporate power game. Dominance guarantees high remuneration and entrenchment.

Agency theory addresses the issues that arise from organizational structure of firms that follow the AngloSaxon firm characteristics. There major differences, relevant to remuneration, between the Anglo-Saxon system and the one in the Continental Europe (Weimer and Pape, 1999) are: (a) Markets for corporate control, capital and labor market for directors are more active and effective (although there is a growing discussion about how efficient they are, (b) Executive managers may entrench themselves in their positions, making it difficult to oust them when they perform poorly (Shleifer and Vishny, 1989; 1997) argue in AngloSaxon countries, capital providers need specialized human capital and executives need capital providers, because they do not have enough capital themselves. On the contrary, in Continental Europe countries, executive directors are capital providers and in many cases, members of the dominant group of stakeholders and (c) The presence of a large shareholder is likely to result in closer monitoring and reduce of executive directors' power to impose the pursuit of their interests (Shleifer and Vishny, 1986).

In Continental Europe countries the fact that major shareholders are members of the BoD, CEOs and Presidents of the BoD, reduces the possibility of monitoring and transparency. These members have triple attributes or roles (major shareholder-part of the dominant group, member of the BoD and CEO-
President of the BoD). Greece is a typical Continental Europe system's country.

Corporate governance status in Greece: Greek firms are mainly family or controlled by a group of stockholders (Mavridis, 2002). Free float is relatively small in percentage (20-50\%) and the ability to achieve control through the capital market is limited. The members of the family or the controlling group are actively involved in management and normally, there is no distinction between management and ownership. The Board of Directors can be characterized as one tier (without a supervisory board). Managers that are not members of the family or the controlling group are closely connected with these groups and their decisions are subject to their control and monitoring. Institutional investors, although they may be the catalyst for the adoption of CG mechanisms, have not actively been involved in management or in controlling and monitoring the decisions and actions of the controlling group.

Mertzanis (2001) (before the new law for the CG in Greece was enacted) noted: "The prevailing framework of corporate governance in Greece is not simply considerably outdated, but may cause potential problems, due to inadequate transparency and accountability, regarding the provision of cost-efficient finance that is required to increase investment and raise national competitiveness". So, the Hellenic Capital Market Committee and the Committee on Corporate Governance have made (44) basic recommendations (compiled in seven main categories: Rights and obligations of shareholders; the equitable treatment of shareholders; the role of stakeholders in corporate governance; transparency, disclosure of information and auditing; the board of directors; the non-executive members of the board of directors; Executive management. They have also proposed the adoption of International Accounting Standards (IAS) (now International Financial Reporting Standards-FRS)). Only a small number of these recommendations have been adopted and introduced.

Spanos (2005) notes that "the majority of medium and small capitalization (family-owned) companies have adopted the minimum mandatory requirements and lack further efficient CG mechanisms. As long as the competition for capital is increasing, listed companies have to realize that proper $\mathrm{CG}$ is a prerequisite in order to attract international capital. Moreover, corporate governance may meet one of the most significant challenges that family-run businesses face: management succession". The need for CG mechanisms is identified by all market participants as a substitute for trust (as a bonding and problem solving 
element) among the major stockholders or family members, but they cannot agree on what the mechanisms/processes will be. Also, major stockholders/family members who are not willing to relinquish power and information control to "non-trust worthy" stockholders or professional executive managers. As a result the governing/administrative bodies do not function according to statutes or laws and the process that they provide, but according to the common will of the family members. Furthermore, an effective market for corporate control does not exist.

The $\mathrm{BoD}$ is mostly acting as a passive body in the company where it follows the decisions of the management. Non-executive board members don't fulfill their role as shareholders' agents to efficiently supervise the management (Schulze et al., 2003). This is the case in the majority of (family) public companies in Greece, where significant costs result from bias in favoring family interests over the firm's interests (such as non-family shareholders), because of loyalty toward the family (Schulze et al., 2003). Even though the rules mandate specific requirements regarding board independence, it's difficult in practice to identify whether the board meets these rules (Spanos, 2005). In countries with concentrated ownership structure (continental Europe, Japan and other OECD countries), large dominant shareholders usually control managers and expropriate minority shareholders, in order to extract private control benefits. The question is therefore posed as how to align the interests of strong block-holders and weak minority shareholders (Noor, 2008; Spanos, 2005; Becht, 1997).

On the other hand, investors usually use their exit options if they disagree with the management or if they are disappointed by the company's performance, signaling-through share price reduction-the necessity for managers to improve firm performance (Spanos, 2005; Hirschman, 1970). The lack of market liquidity creates problems in the effectiveness of the shareholders exit option and governing problems (since the main governing body is the general shareholders meeting, but participation is not an easy task). The cost of involvement with management and control for the minor stockholder is greater than the cost of exit and so they may easily choose to sell their stock ("they vote with their feet") if they are not content with the managements' choices. The shareholders encirclement does not necessarily mean participation in the company administration. In countries where business has traditionally been based on relationship and trust, corporate information is thought of as secret and it is an accepted practice to keep different sets of books, e.g., one for taxes, one for outside investors and one for the majority shareholder (Fremond and Capaul, 2002). There is a vicious circle whereby managers consider secrecy as imperative so that shareholders do not vote with their feet and through it they can cover up their lack of efficiency or impotence; minority shareholders (major shareholders already have the information because they are members of the $\mathrm{BoD}$, management or the relevant cost for them is not too high) do not actively demand information because the cost of acquiring and processing it is too high for them.

Remuneration is considered to be closely connected with financial performance (positively), firm size (positively), the organizational structure (negatively) and corporate governance mechanisms (negatively). Furthermore, a connection of ownership structure and executives' remuneration has been well established (theoretically and empirically) in the literature (agency theory). The study argues that the disclosure of remuneration levels is dependent on variables that are relevant to internal and external mechanisms of CG, performance and growth perspectives.

\section{MATERIALS AND METHODS}

The study analyses data over a period of 6 years (2001-2006). The 60 firms largest, in terms of capitalization and free float, are used. These firms are in the 2 major stock indexes (FTSE-20 and FTSE-40) of the Greek Capital market. Their annual reports are the basic source for the data collection. The data was supplemented by information collected by the corporate web sites. Total sample size is 303 observations. Although remuneration disclosure is mandatory, from the 303 available annual reports only 109 contain information about the executive board members. This is a strong indication of the trend to conceal "sensitive" information. As Alpu and Kurt (2004) argue executives have an incentive to "camouflage" their remunerations, in order to minimize the "outrage" of outsiders. In this case the major shareholders are the stakeholder that conceals information.

To address the issue, limited variable models (Probit) can be used. The Probit model has some significant statistical problems (normality of residuals, heteroscedasticity) and the usual measures of fitness are inefficient. One of the main advantages of probit models is that they allow the use of panel data and also they can take into account the factor of time. A correlation matrix has shown that independent variables are not correlated in a manner $(-0.3 \leq r \geq 0.3)$ that may create problems of result reliability and colinearity. The use of panel variables helps to identify the quality variables that formulate the depended variable. Finally, marginal effects methodology can be applied. Four variables for the construction of panels were used in the present research Table 1. 
Table 1: Variables

\begin{tabular}{|c|c|c|}
\hline Variable & Type & Description \\
\hline Herf & Percentage & Square of the sum of ownership percentages of the biggest five shareholders \\
\hline ROA & Continuous & Return on Assets \\
\hline TQ & Continuous & Tobin's Q \\
\hline CG & Ordinal & $\begin{array}{l}\text { Quality of CG (Lazarides and Drimpetas, 2008), is measured by } 13 \text { binary variables representing } \\
\text { CG good practices (mandatory or not). The binary variables are: } \\
\text { Duality of roles of CEO and president of the board } \\
\text { Audit committee } \\
\text { Number of independent members in audit committee }(\geq 2) \\
\text { Remuneration committee } \\
\text { Nominee committee for board members } \\
\text { Committee for the evaluation and recruitment of executives } \\
\text { Internal statute } \\
\text { Code of ethics-CG } \\
\text { Disclosure of board members' biographical notes } \\
\text { Disclosure of board members' compensation } \\
\text { Disclosure of executives' compensation } \\
\text { Number of independent members }(\geq 3)\end{array}$ \\
\hline MERGER & Binary & $\mathrm{M}-\mathrm{A}(1)$, no M-A (0) \\
\hline $\mathrm{DE}$ & Continuous & Debt Ratio (Debt / Equity) \\
\hline OWNCEO & Binary & Main shareholder is the CEO (1), No (0) \\
\hline CEOCHAIR & Binary & CEO is the President of the board of directors-duality of roles (1), No (2) \\
\hline BOD & Ordinal & Number of members in the board of directors \\
\hline BEXEC & Ordinal & Number of executive board members \\
\hline BPS & Ordinal & Number of firms that the board members participate as members of their board of directors \\
\hline BDIS_P & Percentage & Secessions-resigns of board members to the total number of board members \\
\hline BDISI_P & Percentage & Secessions-resigns of board independent members to the total number of board members \\
\hline TA & Continuous & Total assets \\
\hline SMCAP & Continuous & Stock market capitalization \\
\hline PE & Continuous & Price to equity capital \\
\hline PRICE & Continuous & Stock market share price \\
\hline EMPL & Continuous & Number of employers \\
\hline OC_S2 & Continuous & Square of own capital to sales \\
\hline YEARF & Continuous & Foundation year \\
\hline
\end{tabular}

Model construction: The dependent variable (E_REM) records the decision of the firm to disclose its executives' remunerations. What has been recorded in the study is the cash-salary payments made to the executives. No other way of remuneration (e.g., stock options) could be tracked through annual reports. This may result to the omission of some of the remuneration mechanisms. The omission of these mechanisms, which are important ones in the Anglo-Saxon countries, is less critical for countries like Greece where these mechanisms are rarely used, as in other Continental Europe countries (Kakabadse, 2001).

The model is:

$$
\begin{aligned}
\text { E_ }_{-} \text {REM }_{i t}= & \alpha+\beta_{1} \text { ROA }_{i t}+\beta_{2} \mathrm{TQ}_{i \mathrm{it}}+\beta_{3} \mathrm{CG}_{\mathrm{it}}+\beta_{4} \mathrm{MERGER}_{\mathrm{it}} \\
& +\beta_{5} \mathrm{DE}_{\mathrm{it}}+\beta_{6} \mathrm{HERF}_{\mathrm{it}}+\beta_{7} \mathrm{OWNCEO}_{\mathrm{it}}+\beta_{8} \mathrm{BOD}_{\mathrm{it}} \\
& +\beta_{9} \mathrm{BEXEC}_{\mathrm{it}}+\beta_{10} \mathrm{BPS}_{\mathrm{it}}+\beta_{11} \mathrm{BDIS}_{-} \mathrm{P}_{\mathrm{it}} \\
& +\beta_{12} \mathrm{BDISI}_{-} \mathrm{P}_{\mathrm{it}}+\beta_{13} \mathrm{PRICE}_{\mathrm{it}}+\beta_{14} \mathrm{TA}_{\mathrm{it}} \\
& +\beta_{15} \mathrm{EMPL}_{\mathrm{it}}+\beta_{16} \mathrm{SMCAP}_{\mathrm{it}}+\beta_{17} \mathrm{OC} \mathrm{S}_{\mathrm{it}} \\
& +\beta_{18} \mathrm{OC}_{-} \mathrm{S}_{\mathrm{it}}+\beta_{19} \mathrm{YEARF}_{\mathrm{it}}+\mathrm{u}_{\mathrm{it}}
\end{aligned}
$$

Where:

$$
\begin{aligned}
& \mathrm{i}=1 \ldots \mathrm{N} \\
& \mathrm{t}=1 \ldots \mathrm{T}
\end{aligned}
$$

Disclosure of remuneration of the executives although it is an administrative, but not voluntary decision (Greek law (Law 3016/2002) has relevant provision), is a strong indication of transparency. Good performing firms and firms with growth prospective do not have the incentive to withhold this information. Firms that are managed by professionals have the incentive to link remuneration with performance, as the agency theory suggests.

The variables of CG quality index (for the construction of the index Lazarides and Drimpetas (2008)) and the binary value of mergers and acquisitions should have a positive impact on disclosure of remuneration levels. BoD's size (BoD, number of members), independent BoD members are a measure for the determination of the monitoring efficiency. On the contrary, high numbers of executive members (BEXEC) of the $\mathrm{BoD}$ and secessions-resigns of board members (BDIS_P), to the total number of board members may lead to lower remuneration disclosure levels. 
Firms depending heavily on debt to finance their operations, present high uncertainty and risk for future returns. This, in turn should lead to reduced levels of remuneration disclosures. Large firms have the tendency to depend more on professional managers and hence they have the tendency disclose more their policies and amount regarding remuneration. Concentrated ownership (variables OWN and HERF) has the opposite result. Family or high ownership concentrated firms do not need or they do not have the incentive to release this kind of information to the public. The same conclusions can be drawn for the variance OWNCEO (the biggest shareholder is the CEO).

High investments levels (INVP) are positively related with the disclosure of remuneration levels, if the assumption that investment can lead to better short-term financial results. Otherwise, the relation is negative. Younger firms tend to present higher risks and hence firms are reluctant to have relatively high remuneration levels and in many cases there aren't able to provide cash remuneration. As time passes the firm loses the initial family characteristics due to diffusion of shares (through IPO's, capital increases and succession). This leads to a higher reliance on professional managers.

\section{RESULTS}

Findings-statistical results: The sample was divided in two main categories: (a) the observations of the firms that are ranked in the FTSE-20 index (the biggest 20 firms in terms of capitalization) of the Athens Stock Exchange and (b) the observations of the firms that are ranked in the FTSE-40 index (the next 40 firms in terms of capitalization). No significant differences were found.

Disclosure levels are higher in the Non Financial sector Table 2. Non Financial firms seem to disclose more information than the financial firms. The literature on the subject of disclosure differences between financial and non-financial firms is contradicting. Eng and Mak (2003) report that there are no differences, whereas Boolaky and Thomas (2010) report that the opposite.

As Table 3 depicts, firms with higher ownership concentration, better corporate governance level (Lazarides and Drimpetas, 2008) and better Tobin's Q, seem to disclose more information. Time variance of disclosure is also very interesting. CG seems to affect gradually disclosure. Another point that should be noted is that when disclosure is stratified with ROA then in years 2003 and 2004 disclosure is greater than in the previous and following years. This behavior can be explained if the investment schedules of the firms are taken into account.

The fitness of the model, is satisfactory (McFadden Pseudo $\mathrm{R}^{2}$ is 0.2494 , Log Likehood Function is -148.58 and Estrella is 0.3125). The model can predict the $61.468 \%(67 / 109)$ of the cases that there is disclosure (E_REM variable =1) and the 86.08\% (167/194) of the cases that no disclosure took place $\left(\mathrm{E} \_\right.$REM variable $\left.=0\right)$.

Table 2: Disclose frequency of remuneration in relation with the activity sector

\begin{tabular}{lccc}
\hline & Non financial & Financial & Total \\
\hline Disclosed remuneration & $96(37.1 \%)$ & $13(29.5 \%)$ & $109(36 \%)$ \\
Non disclosed remuneration & $163(62.9 \%)$ & $31(70.5 \%)$ & $194(64 \%)$ \\
Total & $259(100 \%)$ & $44(100 \%)$ & $303(100 \%)$ \\
\hline
\end{tabular}

Table 3: Disclose frequency of remuneration in relation with other variables (2001-2006)

\begin{tabular}{|c|c|c|c|c|c|c|c|}
\hline Disclose & 2001 & 2002 & 2003 & 2004 & 2005 & 2006 & Total \\
\hline \multicolumn{8}{|c|}{ Ownership concentration $(\mathrm{OWN})$-mean } \\
\hline No & 0.53 & 0.53 & 0.53 & 0.48 & 0.48 & 0.47 & 0.50 \\
\hline Yes & 0.59 & 0.60 & 0.54 & 0.55 & 0.61 & 0.52 & 0.57 \\
\hline Total & 0.55 & 0.56 & 0.53 & 0.51 & 0.51 & 0.48 & 0.52 \\
\hline \multicolumn{8}{|c|}{ Corporate Governance index (CGC)-mean } \\
\hline No & 2.16 & 2.11 & 2.28 & 2.93 & 3.00 & 3.03 & 2.64 \\
\hline Yes & 3.35 & 3.76 & 4.40 & 4.13 & 3.92 & 4.42 & 3.97 \\
\hline Total & 2.69 & 2.83 & 3.10 & 3.47 & 3.22 & 3.35 & 3.13 \\
\hline \multicolumn{8}{|c|}{ Return On Assets (ROA)-mean } \\
\hline No & 0.08 & 0.06 & 2.87 & 2.32 & 0.07 & 0.09 & 0.88 \\
\hline Yes & 0.10 & 0.07 & 0.08 & 0.08 & 0.07 & 0.10 & 0.08 \\
\hline Total & 0.08 & 0.06 & 1.80 & 1.31 & 0.07 & 0.10 & 0.59 \\
\hline \multicolumn{8}{|c|}{ Tobin's Q (TQ)-Mean } \\
\hline No & 2.39 & 1.23 & 1.26 & 1.22 & 1.69 & 1.82 & 1.60 \\
\hline Yes & 1.87 & 1.52 & 3.62 & 1.54 & 1.52 & 1.98 & 2.02 \\
\hline Total & 2.16 & 1.36 & 2.17 & 1.37 & 1.65 & 1.86 & 1.75 \\
\hline
\end{tabular}


Am. J. of Economics and Business Administration 2 (4): 341-349, 2010

Table 4: Independent variable statistical significance tests

\begin{tabular}{|c|c|c|c|}
\hline Variable & $\beta$ & St. error & Statistical significance \\
\hline Constant & -0.04069544 & 0.06684466 & 0.5427 \\
\hline MERGER & -0.51686016 & 0.23118191 & $0.0254 * *$ \\
\hline HERF & -0.54085256 & 0.46594677 & 0.2457 \\
\hline INVP & 1.72709874 & 1.04301981 & $0.0977 * * *$ \\
\hline EMPL & $0.452284 \mathrm{D}-04$ & $0.254154 \mathrm{D}-04$ & $0.0751 * * *$ \\
\hline PRICE & -0.03432601 & 0.01759272 & $0.0510 * * *$ \\
\hline SMCAP & -0.00023691 & $0.816376 \mathrm{D}-04$ & $0.0037 * *$ \\
\hline PREMPL & $-0.366606 \mathrm{D}-04$ & 0.00170245 & 0.9828 \\
\hline BOD & -0.13876668 & 0.02814053 & $0.0000^{*}$ \\
\hline BIND & -0.08122871 & 0.05228162 & 0.1203 \\
\hline BEXEC & 0.07691526 & 0.04339091 & $0.0763 * * *$ \\
\hline BPS & -0.01153220 & 0.02598562 & 0.6572 \\
\hline PE & 0.01469979 & 0.00685374 & $0.0320^{* *}$ \\
\hline OC_S2 & -0.02800604 & 0.01216943 & $0.0214 * *$ \\
\hline BDISI_P & -2.73330806 & 1.47221973 & $0.0634 * * *$ \\
\hline BDIS_P & -0.04501015 & 0.42112210 & 0.9149 \\
\hline TA & $0.254997 \mathrm{D}-04$ & $0.114179 \mathrm{D}-04$ & $0.0255^{* *}$ \\
\hline CG & 0.42408891 & 0.02726609 & 0.5241 \\
\hline TQ & 0.04667804 & 0.03307440 & 0.1582 \\
\hline \multicolumn{4}{|c|}{$*: \mathrm{p}<0.01 ; * *: \mathrm{p}<0.05 ; * * *: \mathrm{p}<0.10$} \\
\hline Variable & $\beta$ & St. error & Statistical significance \\
\hline MERGER & -0.5149 & 0.219 & $0.0188^{* *}$ \\
\hline INVP & 1.796 & 0.9455 & $0.0575^{* * *}$ \\
\hline SMCAP & -0.00021 & $0.5996 \mathrm{D}-04$ & $0.0005^{*}$ \\
\hline BOD & -0.1097 & 0.01829 & $0.0000^{*}$ \\
\hline BIND & -0.09522 & 0.50528 & $0.0595 * * *$ \\
\hline OC_S2 & -0.0204 & 0.009511 & $0.0319^{* *}$ \\
\hline BDISI_P & -2.729 & 1.34428 & $0.0423^{* *}$ \\
\hline $\mathrm{TA}$ & $0.21064 \mathrm{D}-04$ & $0.102874 \mathrm{D}-04$ & $0.0406^{* *}$ \\
\hline CG & 0.3799 & 053555 & $0.0000 *$ \\
\hline
\end{tabular}

$*: \mathrm{p}<0.01 ; * *: \mathrm{p}<0.05 ; * * * \mathrm{p}<0.10$

Chi square tests indicate that at least one of the independent variables is statistically significant $\left(\mathrm{X}^{2}[18]\right.$ $($ prob $)=98.71(0.0000))$. The test to identify which independent variables are statistically significant (at the level $\mathrm{a}=0.05$ or $\mathrm{a}=0.10$ ) are shown in the Table 4 that follows. Nine out of 19 variables seem to be statistically significant. An interesting statistical finding is that the Constant term of the Model is not statistically significant. This means that if all independent variables are equal to zero, then the dependent variable is most likely zero as well. This finding is important because it proves that if all other variables are constant there is a tendency to not release any information regarding the executives' remuneration.

The model was further processed to reduce the independent variables, in order to contain only the variables that are statistically significant and to minimize econometric problems (variable EMPL has found to have high correlation with CG and SMCAP and for that reason it was omitted for the model). Although BOD, BIND and CG also present relatively high correlation (0.5-0.6) their omission didn't affect the econometric characteristics of the model.
This procedure has left nine (9) independent variables to be statistically significant (Table 5). The fitness of the final model, is satisfactory (McFadden Pseudo $R^{2}$ is 0.22 , Log Likehood Function is -154.33 and Estrella is 0.2776). The model can predict the $54.13 \%$ (59/109) of the cases where the remuneration policy is disclosed (E_REM variable $=1$ ) and the $85.57 \%$ (166/194) of the cases that no disclosure took place $($ E_REM variable $=0$ ). The combined total prediction capability of the model is $74.26 \%$. Nine out of 19 variables seem to be statistical significant.

Finally, the data were regressed using marginal effects. Marginal effect is the change of possibility due to the change of the independent variable by one unit. Two variables were used to measure their marginal effects on the dependent variable (OwnCEO, CEOCHAIR). The analysis of marginal effects is shown at Table 6.

As Table 6 shows that the combination of roles (shareholder and CEO, chairman of the BoD and CEO) contributes to the tendency of disclosure of executives' remuneration. This finding is a paradox. 
Am. J. of Economics and Business Administration 2 (4): 341-349, 2010

Table 6: Marginal effects

\begin{tabular}{|c|c|c|c|}
\hline \multirow[b]{2}{*}{ Variable } & \multicolumn{3}{|c|}{ Values of group variables } \\
\hline & OWNCEO $=0$ & OWNCEO = 1 & All observations \\
\hline MERGER & -0.05195 & 0.16936 & -0.08104 \\
\hline INVP & 0.18119 & 0.59074 & 0.28266 \\
\hline SMCAP & -0.00002 & -0.00007 & -0.00003 \\
\hline BOD & -0.01107 & -0.03608 & -0.01726 \\
\hline BIND & -0.00961 & -0.03132 & -0.01499 \\
\hline OC_S2 & -0.00206 & -0.00671 & -0.00321 \\
\hline BDISI_P & -0.27531 & -0.89758 & -0.42948 \\
\hline TA & 0.00000 & 0.00001 & 0.00000 \\
\hline \multirow[t]{2}{*}{ CG } & 0.03833 & 0.12496 & 0.05979 \\
\hline & CEOCHAIR $=0$ & CEOCHAIR $=1$ & All observations \\
\hline MERGER & -0.16147 & -0.00783 & -0.08104 \\
\hline INVP & 0.56320 & 0.02730 & 0.28266 \\
\hline SMCAP & -0.00007 & 0.00000 & -0.00003 \\
\hline BOD & -0.03439 & -0.00167 & -0.01726 \\
\hline BIND & -0.02986 & -0.00145 & -0.01499 \\
\hline OC_S2 & -0.00640 & -0.00031 & -0.00321 \\
\hline BDISI_P & -0.85574 & -0.04148 & -0.42948 \\
\hline TA & 0.00001 & 0.00000 & 0.00000 \\
\hline $\mathrm{CG}$ & 0.11913 & 0.00577 & 0.05979 \\
\hline
\end{tabular}

The analysis of CG status, ownership concentration and organizational structure may lead the reader to the conclusion that the concentration of power and control when a person holds two position of power will give the opportunity and capability to these persons to withhold information and to create opacity for the firm's activities. The paradox can be explained by the fact that most of the executives belong to the dominant group or they are closely connected with it. So the firm hasn't anything to lose. On the contrary the firm has the opportunity to show to stakeholders that is compliant with the CG principles of transparency, responsibility and accountability.

\section{DISCUSSION}

One major finding of this study is that only $36 \%$ $(109 / 303)$ of the firms have disclosed in their annual reports the remuneration levels of their executive members, although disclosure is mandatory by law. The selection of non disclosure is conscious. Major shareholders, groups of shareholders and families are the dominant stakeholders in the firm. They are unwilling to release information that may shake the status quo or question their power to make decisions.

The fact that nine variables were found to be statistically significant shows that the phenomenon of remuneration disclosure is complex. Statistically significant variables may be grouped into three major groups. The first group is firm's size (TA, SMCAP, OC_S2), the second the Board of Directors (BoD, BIND, BDISI_P) and the third (MERGER, INVP, CG) the external and growth factor group.
Financial performance was measured with many variables (PREPL, TQ, PE, ROA), but none of them were found to have significant impact on remuneration disclosure. The lack of connection between them is contrary to agency problem theory. Although it seems that stewardship theory might be more valid in the case of Greece, the facts are suggesting differently. The majority of the executives managers are members of or closely connected with the dominant group and those that are not members of the group are directly dependent on it, in order to retain their position. This type of relations formulates a top management team that its main concern is not to produce good financial results but to retain the status quo. This is contrary to the stewardship theory as well. Lazarides et al. (2008) in their empirical study have shown that the level of remuneration in Greece is strongly dependent on financial performance. There should not be any confusion about these findings. The decision to disclose is very different from the decision to regulate remuneration levels using financial performance as a benchmark to evaluate executives. Mergers and Acquisitions (MA) have a negative impact on remuneration disclosure. The reasons are the same as the ones of financial performance.

Time and corporate governance have a surprisingly positive impact on disclosure. Firms are honoring selectively their legal obligations and they are testing their capability to preserve the status quo while, simultaneously, exhibiting to stakeholders their will to be transparent and accountable.

The Board of Directors, its composition and function play a crucial role in disclosure. The duty of 
the BoD is to monitor and control executives, to formulate strategy and to serve as an interface with the external environment. The study did not confirm these duties. Larger BoD (BoD0, bigger number of independent board members (BIND) doesn't seem to have the expected positive impact. The only BoD related variable that has the expected effect is the variable of independent board member dismissalresigns. Independent board members need time to affect firm's principles, policies and tactics. Firm's and especially dominant stakeholder group in their effort to comply with the law, have in their boards sufficient number of independent members, but they do not wish to empower them. So the frequency of independent board member changes is relatively high.

\section{CONCLUSION}

Overall the study has proven that remuneration disclosure levels in Greece are defined by a different set of factors than the ones in a typical Anglo-Saxon country. Mergers have the opposite effect. The agesize of firms, BoD, as well as corporate governance quality have a catalytic impact on remuneration levels) than the ones in an Anglo-Saxon country. Externally imposed mechanisms (BIND, CG) and organizational structures create a trend to homogenize the factors of remuneration disclosure, but their effects are, currently, of minor importance. Policy and regulation makers should take into account these differences and not adopt homeomorphous approaches to different problems and situations.

\section{REFERENCES}

Alpu, O. and G. Kurt, 2004. The effect of socioeconomic and demographic factors on contraceptive use and induced abortion in Turkey. Am. J. Applied Sci., 1: 332-337. DOI: 10.3844/ajassp.2004.332.337

Barney, J. and W. Hesterly, 2007. Strategic Management and Competitive Advantages: Concepts. 2nd Edn., Prentice Hall, USA., ISBN: 10: 013613520X, pp: 380.

Bebchuk, L. and J. Fried, 2004. Pay without Performance: The Unfulfilled Promise of Executive Compensation. 1st Edn., Harvard University Press, MA., ISBN: 10: 0674016653, pp: 304.

Becht, M., 1997. Strong stockholders, weak owners and the need for European mandatory disclosure. European Corporate Governance Network. http://www.ecgi.org/research/control_europe/docu ments/eu.pdf
Boolaky, P.K. and K. Thomas, 2010. Corporate governance compliance and disclosure in the banking sector: Using data from Japan. Social Science Electronic Publishing, Inc. http://ssrn.com/abstract $=1536879$

Cassidy, J., 2002. The greed cycle. The New Yorker. http://www.newyorker.com/archive/2002/09/23/02 0923fa_fact_cassidy

Conyon, M., P. Gregg and S. Machin, 1995. Taking care of business: executive compensation in the United Kingdom. Econ. J., 105: 704-714. http://www.jstor.org/stable/2235029

Conyon, M.J. and S.I. Peck, 1998. Board control, remuneration committee and top management compensation. Acad. Manage. J., 41: 146-157. http://www.jstor.org/stable/257099

Donaldson, L., 1990. The ethereal hand: Organizational economics and management theory. Acad. Manage Rev., 15: 369-381. http://www.jstor.org/stable/258013

Donaldson, L., 1991. Coping with crises: The management of disasters, riots and terrorism. Aust. J. Manage., 16: 99-102.

Eng, L.L. and Y.T. Mak, 2003, Corporate governance and voluntary disclosure. J. Account. Public Policy, 22: 325-345. DOI: 10.1016/S02784254(03)00037-1

Fremond, O. and M. Capaul, 2002. The state of corporate governance: Experience from country assessments. Social Science Electronic Publishing, Inc. http://ssrn.com/abstract $=636222$

Gregg, P., S. Machin and S. Syzmanski, 1993. The disappearing relationship between directors' pay and corporate governance. Br. J. Ind. Relat., 31: $1-9$. DOI: $10.1111 / \mathrm{j} .1467-$ 8543.1993.tb00377.x

Grossman, S.J. and O.D. Hart, 1983. Corporate financial structure and managerial incentives. Social Science Electronic Publishing, Inc. http://ssrn.com/abstract $=578641$

Habib, M.A. and A. Ljungqvist, 2005. Firm value and managerial incentives: A stochastic frontier approach. J. Bus., 78: 2053-2093. DOI: 10.1086/497040

Hassan, S., T. Christopher and R. Evans, 2003. Directors' remuneration and firm performance: Malaysian evidence. Malaysian Account. Rev., 2: 57-67.

Hellwig, M., 1998. On the economics and politics of corporate finance and corporate control. Proceeding of the Conference on Corporate Governance, Oct. 23-24, Institute Catala De Finances, Sitges, pp: 1-49. http://www.sfb504.unimannheim.de/publications/dp98-43.pdf 
Hirschman, A.O., 1970. Exit, Voice and Loyalty: Responses to Decline in Firms, Organizations and States. 3rd Edn., Harvard University Press, Cambridge, MA., ISBN: 10: 0674276604, pp: 176.

Jensen, M.C., K.J. Murphy and E.G. Wruck, 2004. Remuneration: where we've been, how we got to here, what are the problems and how to fix them. Social Science Electronic Publishing, Inc. http://papers.ssrn.com/sol3/papers.cfm?abstract_id $=561305$

Kakabadse, N., 2001. Geopolitics of Governance. 1st Edn., Palgrave Macmillan, New York, ISBN: 0333961277, pp: 128.

Noor, K.B.M., 2008. Case study: A strategic research methodology. Am. J. Applied Sci., 5: 1602-1604. http://www.scipub.org/fulltext/ajas/ajas51116021604.pdf

Lazarides, T.H., E. Drimpetas and D.N. Koufopoulos, 2008. Executive board members' remuneration: A longitudinal study. Corp. Ownership Control, 6: 94-103.

Lazarides, T.G. and E. Drimpetas, 2008. Evaluating corporate governance and identifying its formulating factors: The case of Greece. Social Science Electronic Publishing, Inc. http://papers.ssrn.com/sol3/papers.cfm?abstract_id $=1317629$

Letza, S., J. Kirkbride, X. Sun and C. Smallman, 2008. Corporate governance theorizing: limits, critics and alternatives. Int. J. Law Manage., 50: 17-32. DOI: 10.1108/03090550810852086

Mavridis, D.G., 2002. Marital status aspects disclosed in Greek interims reports. Equal Opport. Int., 8: 1-17. DOI: 10.1108/02610150210787235

Mertzanis, H., 2001. Principles of corporate governance in Greece. Corp. Govern. Int. Rev., 9: 89-100. DOI: 10.1111/1467-8683.00233

Nguyen, H.G., 2005. Using neutral network in predicting corporate failure. J. Soc. Sci., 1: 199-202. http://www.scipub.org/fulltext/jss/jss14199-202.pdf
Petra, S.T., 2005. Do outside independent directors strengthen corporate boards? Corp. Govern., 5: 55-64. DOI: 10.1108/14720700510583476

Samimi, A., H.Z. Aashtiani and A.K. Mohammadian, 2009. A short-term management strategy for improving transit network efficiency. Am. J. Applied Sci., 6: 241-246. DOI: 10.3844/ajassp.2009.241.246

Schulze, W.S., M.H. Lubatkin and R.N. Dino, 2003. Toward a theory of agency and altruism in family firms. J. Bus. Ventur., 18: 473-490. DOI: 10.1016/S0883-9026(03)00054-5

Shleifer, A. and R.W. Vishny, 1986. Large shareholders and corporate control. J. Polit. Econ., 94: 461-488. DOI: $10.1086 / 261385$

Shleifer, A. and R.W. Vishny, 1989. Management entrenchment: The case of manager-specific investments. J. Financ. Econ., 25: 123-139. DOI: 10.1016/0304-405X(89)90099-8

Shleifer, A. and R. Vishny, 1997. A survey of corporate governance. J. Finance, 52: 737-783. http://www.jstor.org/stable/2329497

Spanos, L.J., 2005. Corporate governance in Greece: developments and policy implications. Corp. Govern., $\quad$ 5: 15-30. DOI: $10.1108 / 14720700510583430$

Stulz, R.M., 1990. Managerial discretion and optimal financing policies. J. Financ. Econ., 26: 3-27. DOI: 10.1016/0304-405X(90)90011-N

Van den Berghe, L., 2002. Corporate Governance in a Globalizing World: Convergence or Divergence? A European Perspective. 1st Edn., Springer, Boston, MA., ISBN: 10: 1402071582, pp: 244.

Weimer, J. and J. Pape, 1999. A taxonomy of systems of corporate governance. Corp. Govern. Int. Rev., 7: 152-166. DOI: 10.1111/1467-8683.00143 